\title{
PERAN KEPEMIMPINAN, IKLIM ORGANISASI DANPEMBERDAYAAN DALAM MENINGKATKAN KINERJA KOMITE SEKOLAH
}

\author{
E. Kosmajadi \\ Dosen Pascasarjana Ilmu Administrasi, Universitas Majalengka, Jawa Barat, Indonesia \\ e-mail korespondensi: e.kosmajadi@gmail.com
}

Disubmit Agustus 2019 , Diterima September 2019, Diterbitkan Oktober 2019

Submitted August 2019, Accepted September 2019, Published October 2019

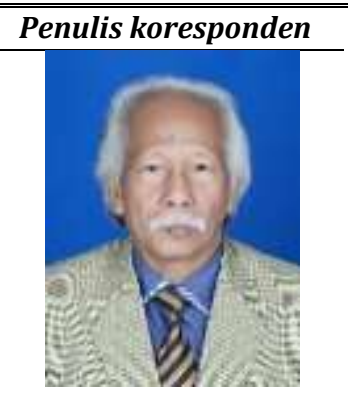

Jurnal DIALOGIKA

diterbitkan oleh

Program Pascasarjana

Administrasi Publik

Universitas Majalengka

\begin{abstract}
The research aims to examine descriptively about leadership, organizational climate, empowerment, and school committee performance and examine verification about the influence of leadership, organizational climate, and empowerment on school committee performance both partially and simultaneously. The method used is descriptive and verification. The population consists of administrators of the State Senior High School Committees in the East Priangan Region with cluster random sampling techniques. Data sources used are primary and secondary data with analysis techniques using path analysis. Descriptive research results prove that leadership, organizational climate, empowerment, and school committee performance are in good condition but there are weaknesses in certain aspects. Verification research results prove that leadership, organizational climate, and empowerment significantly influence the performance of school committees either partially or simultaneously.
\end{abstract}

Keywords: Leadership; Empowerment; Performance, School Committee.

\begin{abstract}
Abstrak
Penelitian bertujuan untuk mengkaji secara deskriptif tentang kepemimpinan, iklim organisasi, pemberdayaan, dan kinerja komite sekolah serta mengkaji secara verifikatif tentang pengaruh kepemimpinan, iklim organisasi, dan pemberdayaan terhadap kinerja komite sekolah baik secara parsial maupun simultan. Metode yang digunakan adalah deskriptif dan verifikatif. Populasi terdiri atas pengurus komite sekolah SLTA Negeri se-Wilayah Priangan Timur dengan teknik cluster random sampling. Sumber data yang digunakan adalah data primer dan sekunder dengan teknik analisis menggunakan path analysis. Hasil penelitian deskriptif membuktikan bahwa kepemimpinan, iklim organisasi, pemberdayaan, dan kinerja komite sekolah dalam kondisi baik tetapi terdapat kelemahan pada aspek tertentu. Hasil penelitian verifikatif membuktikan bahwa kepemimpinan, iklim organisasi, dan pemberdayaan berpengaruh secara signifikan terhadap kinerja komite sekolah baik secara parsial maupun simultan.
\end{abstract}

Kata kunci: Kepemimpinan; Pemberdayaan; Kinerja, Komite Sekolah.

\section{PENDAHULUAN}

Komite Sekolah merupakan badan mandiri yang mewadahi peranserta masyarakat bertujuan untuk menyalurkan aspirasi, meningkatkan tanggung jawab dan peranserta masyarakat, serta menciptakan suasana dan kondisi transfaran, akuntabel, dan demokratis. (Permendiknas RI, No.044/U/2002). Memperhatikan tujuan didirikannya komite sekolah secara garis besar, dapat dipahami betapa beratnya tugas komite sekolah, sehingga untuk dapat melaksanakan tugas dengan baik diperlukan tata kerja yang baik dan kinerja tinggi. Dalam menjalankan peran dan fungsinya pengurus komite sekolah harus mampu memberikan dorongan kepada sekolah untuk meningkatkan pelayanan kepada masya- 
rakat sesuai perkembangan terkini, antara lain mempersiapkan gerenasi muda yang mampu beradaptasi dengan suasana revolusi industri 4.0. Lembaga pendidikan harus mampu menciptakan sumber daya manusia yang memiliki daya saing agar mampu berkompetisi dengan bangsa lain di dunia, karena di era global interaksi sosial tidak lagi sebatas nasional melainkan meluas secara internasional. Jika tidak mau mampu beradaptasi dan tidak mau berubah akan kehilangan kesempatan, karena akan terjadi perubahan cepat, terutama dalam lapangan kerja, melalui otomatisasi (Hamdan,2018; Satya, 2018).

Bagi komite sekolah, untuk dapat menjalankan tugas dan fungsinya dengan baik sesuai harapan diperlukan kinerja tinggi. Kinerja komite sekolah dapat dipengaruhi oleh berbagai faktor, antara lain kepemimpinan, iklim organisasi, dan pemberdayaan yang dapat menjadi dorongan untuk terciptanya kinerja yang lebih baik Pada penelitian sebelumnya telah mengkaji secara empiris bahwa kepemimpinan, iklim organisasi, dan pemberdayaan merupakan faktor-faktor yang memiliki kedudukan penting dalam suatu organisasi, termasuk organisasi komite sekolah kaitannya dengan sistem pendidikan. (Marsofiyati dan Febriana, 2016; Ruth, 2016; Megiati, 2016). Kepemimpinan pada penelitian iniberkaitan dengan fungsinya, yaitu : 1) Fungsi administrasi, meliputi mengadakan formulasi kebijakan administrasi dan menyediakan fasilitas yang diperlukan; 2) Fungsi sebagai Top Management, yakni melakukan ; planning, organizing, staffing, directing, commanding, dan controlling. (Keating, 2003). Ditambah fungsi yang lebih operasional, yakni fungsi kepemimpinan yang terdiri atas lima dimensi, yaitu instruksi, konsultasi, partisipasi, delegasi, dan pengendalian (Nawawi dan Martini, 2004). Dalam organisasi komite sekolah diperlukan seorang pemimpin dengan kepemimpinan yang efektif, yaitu pemimpin yang mampu menggerakkan, mengarahkan, dan mempengaruhi individu atau kelompok untuk melakukan kegiatan organisasi sesuai rencana untuk mencapai tujuan bersama., sehingga kepemimpinan berperan sentral dalam organisasi. (Rahman dan Presetya, 2018; Hardono, Haryono, dan Amin Yusuf,
2017; Rego, Supartha, dan Yasa, 2017).

Selain kepemimpinan, iklim organisasi pun berpengaruh terhadap kinerja komite sekolah. Dalam penelitian ini iklim organisasi diarahkan kepada berfungsinya organisasi secara keseluruhan dari sudut pandang para karyawan, diukur melalui enam dimensi, yaitu: a) Struktur, meliputi pengorganisasian karyawan, pembagian tugas, dan penempatan pegawai; b) Standar- standar, meliputi rasa bangga menjadi pegawai dan kondisi lingkungan kerja; c) Tanggungjawab, meliputi rasa percaya diri; d) pegawai, mampu menjalankan tugas sendiri; d) Pengakuan, meliputi imbalan yang layak dan penghargaan setelah selesai melakukan pekerjaan; e) Dukungan, meliputi dukungan pegawai terhadap organisasi, dukungan teman dalam kelompok, dan dukungan pemimpin terhadap pegawai; e) Komitment, meliputi memahami tujuan organisasi, dan bersedia mewujudkan tujuan organisasi. (Thomas (2007).

Dalam suatu organisasi iklim organisasi akan terjadi dan mempengaruhi perilaku anggota organisasi sehingga berdampak pada kinerja organisasi. Oleh karena itu iklim organisasi menjadi unsur penting, karena memberikan nilai dan sikap pegawai yang positif dalam mencapai tujuan organisasi. Iklim organsiai yang tercipta akan menjadi unsur pembeda dengan organisasi lainnya. (Yehezkiel dan Anggraeny, 2014; Radianto dan Sunuharjo, 2017; Setiawan, 2015). Faktor lain yang dapat mempengaruhi kinerja komite sekolah adalah faktor pemberdayaan. Dalam penelitian ini pemberdayaan berkaitan dengan dua hal, yakni siklus dan proses pemberdayaan. Siklus pemberdayaan meliputi ; 1) Keinginanuntuk berubah; 2) Melepaskan halangan- halangan; 3) Rasa memiliki bertambah; 4) Mengembangkan peran dan batas tanggungjawab; 5) Pencapaian hasil dan target yang lebih besar; 6) Perubahan perilaku dan kesan terhadap dirinya; 7) Merasa tertantang untuk upaya yang lebih besar. (Wilson,2000). Ditambah dengan pemberdayaan yang erat kaitannya dengan proses, yaitu pemberdayaan yang menuntut lebih banyak kecakapan dan sumber daya manajerial menuntut digunakannya sepe- 
rangkat kecakapan baru, yaitu membuat mampu(enabling), memperlancar (facilitating), berkonsultasi (consultating), bekerja sama (collaborating), membimbing (mentoring), dan mendukung (supporting) (Hardjana, 2008).

Dalam upaya meningkatkan kualitas kerja organisasi, pemberdayaan merupakan salah satu alternatif yang dapat dilakukan. Pemberdayaan (empowerment) digunakan untuk sumberdaya yang telah memiliki potensi tetapi belum digunakan secara optimal, bertujuan untuk membantu agar berdaya, mampu mengambil keputusan, dan memiliki kemandirian. Karena pada hakikatnya pemberdayaan mendorong seseorang agar mampu berubah. (Megiati, 2016; Marsofiyati dan Febriantina, Susan, 2016; Nyandoro, 2013).

Istilah kinerja memiliki makna berbeda, antara lain diartikan sebagai "sesuatu yang dicapai; prestasi yang diperlihatkan; dan kemampuan kerja" (KBBI Online). Pendapat lain menyatakan kinerja adalah tentang melakukan pekerjaan dan hasil yang dicapai dalam pekerjaan tersebut (Wibowo, 2011). Kinerja komite sekolah secara teoretis memiliki makna yang sama dengan kinerja organisasi, di mana untuk mewujudkannya diperlukan manajemen kinerja, yang diyakini dapat memperkuat kinerja organisasi. (Hartajunika, 2015). Dalam penelitian ini kinerja organisasi komite sekolah, diukur dari tujuan dan peranannya. Pembentukan komite sekolah bertujuan untuk: 1) Mewadahi dan menyalurkan aspirasi dan prakarsa masyarakat dalam melahirkan kebijakan operasional dan program pendidikan di satuanpendidikan; 2) Meningkatkan tanggung jawab dan peran serta masyarakat dalam penyelenggaraan pendidikan di satuan pendidikan; 3) Menciptakan suasana dan kondisi transparan, akuntabel, dan demokratis dalam penyelenggaraan dan pelayanan pendidikan yang bermutu di satuan pendidikan. Dalam upaya mencapai tujuan tersebut, komite sekolah dituntut untuk dapat menjalankan perannya sebagaiadvisory agency, supporting agency, controlling agency, dan mediator (Permendiknas, No. 044/U/2002). Secara operasional, masing- masing peran memiliki objek tersendiri, sebagai berikut; 1) Peran sebagai Advisory Agency, meliputi ; kebijakan pendidikan, program pendidikan, RAPBS, kriteria kinerja satuan pendidikan, kriteria kinerja tenaga kependidikan, dan kriteria fasilitas pendidikan; 2) Peran sebagai Supporting Agency, meliputi : mendorong orang tua siswa dan masyarakat untuk berpartisipasi dalam pendidikan, menggalang dana masyarakat membiayai penyelenggaraan pendidikan, dan mendorong tumbuhnya perhatian dan komitment masyarakat terhadap penyelenggaraan pendidikan yang bermutu; 3) Peran sebagai Controlling Agency, melakukan evaluasi dan pengawasanterhadap : kebijakan pendidikan, program pendidikan, penyelenggaraan pendidikan, dan keluaran pendidikan; 4) Peran sebagai Mediator, meliputi ; melakukan kerjasama dengan masyarakat, menampung aspirasi, ide, tuntutan, dan kebutuhan pendidikan yang diajukan masyarakat; dan menganalisis ide, tuntutan, dan kebutuhan pendidikan yang diajukan masyarakat.

Dalam prakteknya, pelaksanaan peran tersebut belum merata, sehingga kinerja komite sekolah masih tergolong rendah. Dari hasil observasi awal, terdapat beberapa alasan yang menjadi peyebab rendahnya kinerja komite sekolah, antara lain : a) Kebanyakan ketua pengurus komite sekolah memiliki jabatan di organisasi/instansi lain sehingga tidak fokus memimpin komite sekolah ; b) Kebanyakan komite sekolah tidak memiliki kantor/sekretariat yang memadai; c) Sinergi antara pengurus komite sekolah dengan kepala sekolah bervariasi; d) Tidak ada upaya pemberdayaan iternal; dan e) kepemimpinan yang lemah. Oleh karena itu, berdasarkan masalah yang dihadapi komite sekolah diperlukan solusi untuk meningkatkan kinerja komite sekolah yang pada gilirannya diharapkan dapat memberikan peran positif kepada sekolah. Solusi yang dapat dilakukan antara lain : a) Melengkapi fasilitas, sekurangkurangnya ada ruangan khusus untuk dijadikan pusat aktivitas komite sekolah; b) Mengadakan pelatihan bagi pengurus komite sekolah untuk meningkatkan kompetensi sesuai dengan fungsi; c) Bekerja sama dan berkoordinasi dengan Dewan Pendidikan guna memperoleh fasilitas pendidikan dan pelatihan atau kegiatan lain yang relevan; d) Pendampingan penerapan manajemen sumber daya manusia guna memantapkan kepemimpinan dan pemberdayaan internal. 
Dari alternatif solusi yang ditawarkan, solusi yang paling urgent, essensisl, dan bermanfaat untuk segera dilakukan pemecahan adalah kepemimpinan, iklim organisasi, dan pemberdayaan. Maka, penelitian ini bertujuan untuk mengetahui pengaruh kepemimpinan, iklim organisasi, dan pemberdayaan terhadap kinerja komite sekolah. Hasil penelitian, diharapkan bermanfaat untuk memperkuat organisasi komite sekolah dengan kepemimpinan yang kuat dan berintegritas, iklim organisasi yang kondusif, serta membuat pengurus komite semakin berdaya, mampu mengambil keputusan dengan capat, lebih mandiri, bertanggung jawab, berkomitment tinggi dan lebih kreatif sehingga mampu menjalankan peran komite sekolah, baik sebagai advisory agency, supporting agency, controlling agency, maupun sebagai mediator. Lebih jauh diharapkan dapat memberikan dampak positif terhadap penyelenggaraan pendidikan formal secara menyeluruh.

\section{METODE PENELITIAN}

Penelitian dilakukan di Komite Sekolah SLTA se-Wilayah Priangan Timur, provinsi Jawa Barat selama tujuh bulan. Metode yang digunakan adalah deskriptif- verifikatif dengan pendekatan kuantitatif. Data dikumpulkan menggunakan kuesioner yang disebar kepada 124 komite sekolah, yang ditetapkan berdasarkan teknik Cluster Random Sampling. Pengisian kuesioner diwakili oleh pengurus masing-masing tiga orang.

Sumber data terdiri atas dua jenis, yaitu data primer dan data sekuder. Data yang diperoleh dianalisis melalui dua cara, yaitu analisis deskriptif untuk mengidentifikasi variabel independent yangditeliti, identifikasi menggunakan metode interval score dengan pembagian median dananalisis statistik untuk mengidentifikasi keberadaan data agar mudah untuk diketahui, dan mempermudah untuk pengambilan kesimpulan menggunakan pendekatan statistik. Teknik analisis statistik yang digunakan adalah statistik inferensial, yakni menggunakan perhitungan korelasi, regresi, t-tes, uji $\mathrm{F}$, dan uji determinasi. Rancangan analisis terdiri atas transformasi data menggunakan $M S I$, metode analisis data menggunakan analisis jalur, pengujian hipotesis dengan t-test dan F-test.

\section{HASIL DAN PEMBAHASAN}

Berdasarkan hasil penelitian tentang kepemimpinan, iklim organisasi, dan pemberdayaan terhadap kinerja komite sekolah, diperoleh data melalui penyebaran kuesioner kemudian dianalisis baik secara deskriptif maupun verifikatif, hasilnya sebagai berikut :

\section{Hasil Analisis deskpriptif}

Hasil penelitian deskriptif, diperoleh dari pengolahan data berdasarkan jawaban responden melalui penyebaran kuesioner. Kuesioner disusun berdasarkan skala likert, disediakan lima alternatif jawaban. Untuk keperluan analisis masing-masing diberi bobot berjenjang 5,4,3,2,1. Hasil disajikan pada tabel 1 di bawah ini.

Tabel 1. Rekapitulasi Hasil Analisis Deskriptif Kepemimpinan $\left(\mathrm{X}_{1}\right)$, Iklim Organisasi $\left(\mathrm{X}_{2}\right)$, Pemberdayaan $\left(\mathrm{X}_{3}\right)$, dan Kinerja Komite Sekolah

\begin{tabular}{|c|c|c|c|c|}
\hline \multirow{2}{*}{ Var. } & \multicolumn{2}{|c|}{ Rata-Rata } & \multirow{2}{*}{$\begin{array}{c}\text { Rentang } \\
\text { Nilai }\end{array}$} & \multirow{2}{*}{ Katagori } \\
\hline & Skor & St.Dev. & & \\
\hline $\mathrm{X}_{1}$ & 3,4537 & 0,5231 & $\begin{array}{c}3,1290 \text { s.d } \\
3,5645\end{array}$ & $\begin{array}{c}\text { Cukup Baik s.d } \\
\text { Baik }\end{array}$ \\
\hline $\mathrm{X}_{2}$ & 3,4444 & 0,4966 & $\begin{array}{c}3,0242 \text { s.d } \\
3,6935\end{array}$ & $\begin{array}{l}\text { Cukup } \\
\text { Kondusif s.d } \\
\text { Kondusif }\end{array}$ \\
\hline $\mathrm{X}_{3}$ & 3,3653 & 0,5066 & $\begin{array}{c}3,1855 \text { s.d } \\
3,7661\end{array}$ & $\begin{array}{l}\text { Cukup Baik s.d } \\
\text { Baik }\end{array}$ \\
\hline Y & 3,5706 & 0,4818 & $\begin{array}{c}3,2419 \text { s.d } \\
3,8226\end{array}$ & $\begin{array}{l}\text { Cukup Tinggi } \\
\text { s.d Tinggi }\end{array}$ \\
\hline
\end{tabular}

Sumber: Hasil Penelitian, data diolah

Berdasarkan data yang disajikan pada tabel 1, dapat dijelaskan bahwa untuk mengetahui kondisi kepemimpinan disebarkan 16 butir kuesioner. Dari hasil analisis diketahui rata-rata skor sebesar 3,4537, rata-rata standar deviasi 0,5231,

rentang nilai antara 3,1290 sampai 3,5645 dengan kategori cukup baik sampai baik. Untuk mengetahui iklim organisasi disebarkan 15 butir kuesioner. Dari hasil analisis diketahui rata-rata skor sebesar 3,4444, rata-rata standar deviasi 0,4966, rentang nilai antara 3,0242 s.d 3,6935 dengan kategori cukup kondusif sampai kondusif. Untuk mengetahui kondisi pem- berdayaan, disebarkan 15 butir kuesioner. Dari hasil analisis diketahui rata-rata skor sebesar 3,3653, rata-rata standar deviasi 0,5066, rentang nilai antara 3,1855 sampai 3,7661 dengan kategori cukup baik sampai baik. Untuk mengetahui kondisi kinerja komite 
sekolah, disebarkan kuesioner sebanyak 16 butir. Dari hasil analisis diketahui rata-rata skor sebesar 3,5706, rata-rata standar deviasi 0,4818 , rentang nilai antara 3,2419 sampai 3,8226 dengan kategori cukup tinggi sampai tinggi.

Berdasarkan uraian deskripsi terhadap jawaban responden untuk masingmasing variabel, disimpulkan kriteria ketercapaian tiap-tiap variabel sebagaimana disajikan pada tabel 2 di bawah ini.

Tabel 2, Rata-rata dan Standar Deviasi

\begin{tabular}{lccc}
\hline \multicolumn{1}{c}{ Variabel Penelitian } & N & Mean & $\begin{array}{c}\text { Std. } \\
\text { Deviation }\end{array}$ \\
Kepemimpinan & 124 & 3,4537 & 0,5231 \\
Iklim Organisasi & 124 & 3,4444 & 0,4966 \\
Pemberdayaan & 124 & 3,3653 & 0,5066 \\
Kinerja Komite Sekolah & 124 & 3,5706 & 0,4818 \\
Valid N (listwise) & 124 & - & - \\
\hline
\end{tabular}

Sumber : Hasil Penelitian, Data diolah

Data pada Tabel 2 menunjukkan skor rata-rata variabel pemberdayaan lebihrendah dibandingkan variabel lainnya. Sedangkan skor rata-rata untuk variabel kinerja komite sekolah lebih tinggi dibandingkan variabel lainnya. Disamping itu, tabel 2 menginformasikan bahwa untuk variabel bebas kepemimpinan mempunyai variasi lebih tinggi dibandingkan variabel bebas lainnya.

\section{Hasil Analisis Verifikatif}

Analisis verifikatif dilakukan terhadap data hasil jawaban responden diolah dengan pendakatan statistik. Tabel di bawah ini menampilkan hasil pengolahan data keterkaitan antar variabel yang diteliti.

Tabel 3. Korelasi antar variabel

\begin{tabular}{|c|c|c|c|c|}
\hline & & $\mathbf{X 1}$ & $\mathrm{X} 2$ & X3 \\
\hline \multirow[t]{3}{*}{$\begin{array}{l}\text { Kepemimpin } \\
\text { an(X1) }\end{array}$} & $\begin{array}{l}\text { Pearson } \\
\text { Correlation }\end{array}$ & 1 & 0,500 & 0,381 \\
\hline & Sig. (2-tailed) & & .000 & .000 \\
\hline & $\mathrm{N}$ & 124 & 124 & 124 \\
\hline \multirow{3}{*}{$\begin{array}{l}\text { Iklim } \\
\text { Organisasi } \\
\text { (X2) }\end{array}$} & $\begin{array}{l}\text { Pearson } \\
\text { Correlation }\end{array}$ & 0,500 & 1 & 0,620 \\
\hline & Sig. (2-tailed) & .000 & & .000 \\
\hline & $\mathrm{N}$ & 124 & 124 & 124 \\
\hline \multirow[t]{3}{*}{$\begin{array}{l}\text { Pemberdayaan } \\
\text { (X3) }\end{array}$} & $\begin{array}{l}\text { Pearson } \\
\text { Correlation }\end{array}$ & 0,381 & 0,620 & 1 \\
\hline & Sig. (2-tailed) & .000 & .000 & \\
\hline & $\mathrm{N}$ & 124 & 124 & 124 \\
\hline
\end{tabular}

Dari data yang tertera pada tabel 3, dapat dijelaskan bahwa hubungan kepemimpinan dengan iklim organisasi diperoleh nilai sebesar 0,500 dengan kriteria hubungan yang sedang dan searah, artinya apabila terdapat peningkatan satu satuan dari kepemimpinan akan meningkatkan iklim organisasi sebesar 0,500, begitu pula sebaliknya. Hubungan kepemimpinandengan pemberdayaan diperoleh nilai sebesar 0,381 dengan kriteria hubungan yang lemah dan searah, artinya apabila terdapat peningkatan satu satuan dari kepemimpinan akan meningkatkan pember- dayaan sebesar 0,381, begitu pula sebaliknya. Hubungan iklim organisasi dengan pemberdayaan diperoleh nilai sebesar 0,620 dengan tingkat hubungan kuat dan searah, artinya apabila terdapat peningkatan satu satuan dari iklimorganisasi akan meningkatkan pemberda- yaan sebesar 0,620 , begitu pula sebaliknya.

Hasil pengujian jalur dengan menggunakan bantuan komputer program SPSS for Window versi 17,00, diperoleh hasil sebagai berikut.

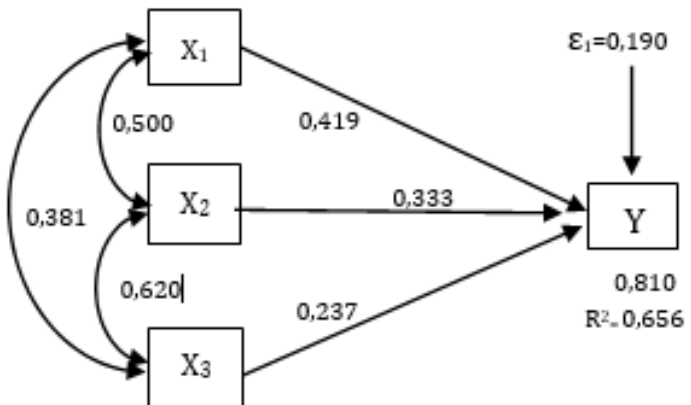

Gambar 1. Hasil Pengujian Jalur

Sumber : Hasil Perhitungan SPSS.

Dari gambar 1 dapat dijelaskan besaran derajat asosiatif atau koefisien jalur dari masing-masing variabel bebas terhadap variabel terikat, untuk jelasnya dapat dilihat pada tabel di bawah ini :

Tabel 4. Koefisien Jalur X1, X2, X3 terhadap Variabel Y

\begin{tabular}{lcc}
\hline \multicolumn{1}{c}{ Variabel } & & Koefisien Jalur \\
\cline { 1 - 1 } Kepemimpinan $\left(\mathrm{X}_{1}\right)$ & & 0,419 \\
Iklim Organisasi $\left(\mathrm{X}_{2}\right)$ & 0,333 \\
Pemberdayaan $\left(\mathrm{X}_{3}\right)$ & & 0,237 \\
\hline
\end{tabular}

Sumber: hasil penelitian

Data pada Tabel 4. menunjukkanbahwa variabel kepemimpinan memiliki nilai koefisien jalur yang tertinggi dibandingkan dengan iklim organisasi dan pemberdayaan. 
Berdasarkan kepada Tabel 4 dapat diperoleh persamaan jalur, yaitu :

$$
\begin{aligned}
& Y=0,419 X_{1}+0,333 X_{2}+0,237 X_{3}+\varepsilon_{1} \\
& Z=0,878 Y+\varepsilon_{2}
\end{aligned}
$$

Dari persamaan tersebut dapat dijelaskan : Terdapat hubungan asosiatif kepemimpinan dengan kinerja komite

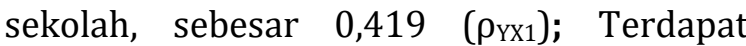
hubungan asosiatif iklim organisasi dengan kinerja komite sekolah, sebesar 0,333 $\left(\rho_{\mathrm{YX} 2}\right)$; Terdapat hubungan asosiatif pemberdayaan dengan kinerja komite sekolah, sebesar0,237. ( $\left.\rho_{\text {YX3 }}\right)$. Sesuai dengan hipotesis penelitian, hasil pengolahan data untuk membuktikan pengaruh langsung dan tidak langsung setiap variabel disajikan dalam Tabel sebagai berikut:

Tabel 5. Pengaruh Total, Langsung dan

\begin{tabular}{|c|c|c|c|c|c|c|}
\hline \multirow[b]{2}{*}{ Var } & \multirow{2}{*}{$\begin{array}{l}\text { Pengaruh } \\
\text { Langsung }\end{array}$} & \multicolumn{3}{|c|}{ Pengaru h Tidak L angsung } & \multirow{2}{*}{$\begin{array}{l}\text { Total } \\
\text { PTL }\end{array}$} & \multirow{2}{*}{$\begin{array}{c}\text { Total } \\
\text { Pengaruh }\end{array}$} \\
\hline & & $X_{1}$ & $X_{2}$ & $\mathrm{X}_{3}$ & & \\
\hline $\mathrm{X}_{1}$ & 0,1756 & & 0,0698 & 0,0378 & 0,1076 & 0,2833 \\
\hline $\mathrm{X}_{2}$ & 0,1109 & 0,0698 & & 0,0489 & 0,1187 & 0,2297 \\
\hline $\mathrm{X}_{3}$ & 0,0562 & 0,0378 & 0,0489 & & 0,0867 & 0,1430 \\
\hline \multicolumn{5}{|c|}{ Total Pengaruh X terhadap Y } & & 0,6560 \\
\hline
\end{tabular}
Tidak langsung

Sumber: hasil penelitian

Berdasarkan data yang tertera pada tabel 5 di atas, dapat diketahui bahwa masingmasing variabel bebas secara parsial berpengaruh terhadap variabel terikat, baik langsung maupun tidak langsung. Secara kumulatif, semua variabel bebas memiliki total pengaruh terhadap variabel terikat sebesar 0,6560. Artinya, apabila ketiga variabel bebas tersebut digabungkan memberi pengaruh secara bersama terhadap variabel terikat dan saling memperkuat, Kemudian, tahap paling penting dalam analisis verifikatif adalah pengujianhipotesis, dengan hasil sebagai berikut.

\begin{tabular}{|c|c|c|c|c|}
\hline $\begin{array}{l}\text { Struk } \\
\text { tural }\end{array}$ & $\begin{array}{l}\text { Koefisien } \\
\text { jalur }\end{array}$ & $\begin{array}{c}\mathrm{t}- \\
\text { hitung }\end{array}$ & $\begin{array}{c}\mathrm{t}- \\
\text { tabel }\end{array}$ & Kesimpulan \\
\hline px1y & 0,419 & 6,741 & 1,960 & $\begin{array}{lr}\mathbf{H}_{\mathbf{0}} \text { ditolak, } & \text { terdapat } \\
\text { pengaruh signifikan } \\
\text { dari kepemimpinan } \\
\text { terhadap } & \text { kinerja } \\
\text { komite sekolah }\end{array}$ \\
\hline$p x 2 y$ & 0,333 & 4,538 & 1,960 & $\begin{array}{lr}\mathbf{H}_{\mathbf{0}} \text { ditolak, } & \text { terdapat } \\
\text { pengaruh } & \text { signifikan } \\
\text { dari iklim } & \text { organisas } \\
\text { terhadap } & \text { kinerja } \\
\text { komite sekolah } & \end{array}$ \\
\hline px3y & 0,237 & 3,452 & 1,960 & $\begin{array}{l}\mathbf{H}_{\mathbf{0}} \text { ditolak, terdapat } \\
\text { pengaruh signifikan } \\
\text { dari } \\
\text { pemberdayaanterhadap } \\
\text { kineria komite sekolah }\end{array}$ \\
\hline
\end{tabular}

Tabel 6, Hasil Pengujian Hipotesis

Sumber: hasil penelitian

\section{PENUTUP}

Pengaruh kepemimpinan dan Good governance terhadap Kinerja pegawai Berdasarkan hasil pengolahan data menggunakan SPSS, diperoleh data yang menunjukkan bahwa secara parsial kepemimpinan berpengaruh signifikan terhadap kinerja pegawai sebesar 47,57\%, sementara good governance memberikan pengaruh terhadap kinerja pegawai sebesar $42,10 \%$. Hasil penelitian secara simultan kepemimpinan dan good governance terhadap kinerja pegawai sebesar 89,70\% dan sisanya sebesar $10,30 \%$ dipengaruhi oleh variabel lain diluar penelitian. Hasil penelitian ini telah membuktikan secara empiris bahwa Prinsip-prinsip dalam kepemimpinan telah diimplementasikan dengan cukup baik.

Peneliti berharap Dinas Perdagangan dan Perindustrian di Kabupaten Majalengka dapat mempertahankan prinsip dalam kepemimpinannya, begitupun dengan hasil pelaksanaan good governance telah dilaksanakan dengan cukup baik. Hal ini menunjukkan bahwa pelaksanaan prinsipprinsip good governance untuk dipertahankan dan bila perlu ditingkatkan dalam rangka memberikan pelayanan public yang lebih berkualitas. Untuk pelaksanaan kinerja pegawai juga telah menunjukkan hasil yang cukup baik, meskipun faktor kemandirian harus ditingkatkan melalui pelatihan-pelatihan yang dilakukan.

Dari data yang tertera pada tabel 6 diketahui bahwa kepemimpinan, iklim organisasi, dan pemberdayaan terbukti berpengaruh terhadap kinerja komite sekolah secara signifikan. Kemudian, untuk menguji hipotesis pengaruh kepemimpinan, ikim organisasi, dan pemberdayaan terhadap kinerja komite sekolah secara simultan, diuji dengan Uji-F. Dari hasil pengujian diketahui Fhitung $(76,200)$ lebih besar dari $F_{\text {-tabel }}$ dengan derajat bebas $\mathrm{v}_{1}=3$ dan $\mathrm{v}_{2}=124-3-1$ dan tingkat kepercayaan 95\%, maka dari tabel distribusi $\mathrm{F}$ didapat nilai $\mathrm{F}_{\text {tabel }}$ untuk $\mathrm{F}_{0,05.3,125}=$ 2.88. Artinya, kepemimpinan, iklim organisasi, dan pemberdayaan berpengaruh signifikan terhadap kinerja komite sekolah secara simultan, dengan koefisien determinasinya sebesar $\left(\mathrm{R}^{2}\right)=0,656$ atau $65,60 \%$ dan pengaruh variabel di luar model sebesar 34,40 \% (Errorvar $=0,190$ ). 


\section{Pembahasan Deskriptif.}

Hasil analisis deskriptif menunjukkan bahwa kepemimpinan telah dilaksanakan dengan baik sesuai dengan tugas pokok dan fungsinya. Pada umumnya responden memberikan tanggapan positif, dalam arti ketua telah menjalankan fungsi kepemimpinannya yang ditandai dengan rata-rata skor yang paling tinggi, yaitu tentang pengawasan, pelimpahan tanggungjawab, dan menetapkan keputusan dengan pertimbangan. Meskipun demikian masih terdapat kekurangan yang harus diperbaiki, yaitu dalam hal mengaktifkan anggota untuk melaksanakan suatu keputusan dan menentukan tempat mengerjakan perintah,dengan rata-rata skor jawaban responden hanya 3,13 yang merupakan temuan empiris untuk variabel kepemimpinan. Hal ini disebabkan karena lemahnya ketua dalam menumbuhkan kesadaran kepada anggota tentang tanggungjawab pelaksanaan tugas dan kondisi kantor yang kurang memadai. Jika dikaitkan dengan hasil observasi awalbahwa kepemimpinan lemah, hasil paparan ini mampu menjelaskan kondisi yang sebenarnya.

Hasil analisis deskripsi mengenai iklim organisasi, secara umum iklim organisasi berada pada kondisi yang kondusif. Responden memberikan tanggapan positif, dalam arti iklim organisasi telah tercipta kondusif sebagai penunjang peningkatan kualitas kerja anggota dan organisasi. Kondusifnya iklim organisasi komite sekolah terutama pada pembagian tugas dan kondisi lingkungan kerja, digambarkan dengan skor paling tinggi. Pembagian tugas yang baik tentu berpengaruhi terhadap suasana organisasi yang kondusif, karena pembagian tugas yang baik memungkinkan masingmasing memiliki batas tanggung jawab yang jelas. Apalagi jika didukung oleh lingkungan kerja yang nyaman. Namun demikian, ditemukan juga jawaban responden yang rendah, antara lain tentang tingkatkelayakan imbalan dan kurangnya penghargaan kepada anggota setelah melaksanakan pekerjaan. Dengan demikian, apabila ketua bermaksud meningkatkan iklim organisasi yang lebih kondusif, ketua harus memikirkan agar imbalan bagi anggota lebih layak dan memadai. Selain itu, pemberian penghargaan kepada setiap anggota yang telah selesai melaksanakan pekerjaan penting untuk diperhatikan.

Hasil analisis deskripsi mengenai variabel pemberdayaan, secara umum berada pada kondisi yang baik. Responden memberikan tanggapan positif, dalam arti pemberdayaan telah dilaksanakan dengan baik sebagai upaya meningkatkan kemampuan pengurus agar berdaya, mandiri, dan sanggup mengambil keputusan sediri dalam menjalankan tugas dan fungsinya sebagai pengurus komite sekolah. Telah baiknya pemberdayaan terutama dalam keinginan anggota untuk berubah, yang menurut responden berada pada kategori baik dan tentang pencapaian hasil dan target yang lebih besar. Namun demikian, masih terdapat kelemahan dalam hal membuat mampu (enabling) dan bekerja sama yang termasuk indikator proses pemberdayaan, nilainya hanya mencapai $3,18 \%$ yang merupakan temuan empiris bagi pemberdayaan. Dampaknya, pengurus komite sekolah masih ada yang belum mampu menjalankan fungsinya secara optimal karena keterbatasan kemampuan dan kurang bekerjasama.

Dari hasil analisis deskriptif menunjukkan kinerja komite sekolah telah berada pada kondisi cukup baik. Umumnya responden memberikan tanggapan positif, dalam arti ketua dan pengurus yang lain telah menjalankan fungsinya ditandai dengan ratarata skor yang paling tinggi, tentang menjalankan peran dan fungsinya dalam memberikan pertimbangan terhadap pembuatan RAPBS dan pengawasan terhadap program pendidikan. Namun masih terdapat kelemahan dalam hal memberi pertimbangan mengenai kriteria kinerja tenaga kependidikan dan menjadi mediator.

\section{Pembahasan Verifikatif.}

Hasil analisis jalur diperoleh derajat asosiatif dengan penjelasan bahwa terdapat hubungan asosiatif kepemimpinan dengan kinerja komite sekolah, sebesar 0,419 ( $\left.\rho_{\text {Yx1 }}\right)$; terdapat hubungan asosiatif iklim organisasi dengan kinerja komite sekolah, sebesar 0,333 $\left(\rho_{\mathrm{YX} 2}\right)$ dan terdapat hubungan asosiatif pemberdayaan dengan kinerja komite sekolah, sebesar 0,237 ( $\left.\rho_{\mathrm{YX}}\right)$. Dengan demikian dapat dipahami bahwa variabelvariabel yang diteliti merupakan faktor- 
faktor yang saling berkaitan dalam satu lingkungan organisasi, dalam hal ini organisasi komite sekolah. Kinerja komite sekolah erat kaitannya dengan variabel kepemimpinan, iklim organisasi, dan pemberdayaan karena memang kinerja organisasi terbentuk atas peran ketiga faktor tersebut. Hanya memang faktor sentral ada pada kepemimpinan, karena kepemimpinan yang menjadi subjek terciptanya iklim organisasi dan terselenggaranya proses pemberdayaan.

Dari data yang tertera pada tabel 5 , secara parsial variabel kepemimpinan memiliki pengaruh langsung terhadap kinerja komite sekolah sebesar 0,1756 $(17,56 \%)$. pengaruh tidak langsung melalui iklim organisasi sebesar 0,0698 (6,98\%), pengaruh tidak langsung melalui pemberdayaan sebesar $0,0378(3,78 \%)$, sehingga diketahui total pengaruh tidak langsung kepemimpinan terhadap kinerja komite sekolah sebesar 0,1076 (10,76\%), dan total pengaruh kepemimpinan terhadap kinerja komite sekolah sebesar 0,2833 (28,33\%). Adanya pengaruh kepemimpinan terhadap kinerja komite sekilah secara parsial diperkuat oleh hasil uji hipotesis yang signifikan, juga relevan dengan hasil analisis deskriptif di mana kepemimpinan berada pada kondisi cukup baik. Hail penelitian ini memperkuat teori yang dikemukakan Hersey dan Blanchard (2009) yang menjelaskan bahwa kepemimpinan adalah proses mempengaruhi kegiatan-kegiatan seseorang atau sekelompok orang untuk mencapai tujuan dalam suatu situasi tertentu.

Kemudian, secara parsial iklim organisasi memiliki pengaruh langsung terhadap kinerja komite sekolah sebesar $0,1109(11,09 \%)$, pengaruh tidak langsung melalui kepemimpinan sebesar 0,0698 $(6,98 \%)$, pengaruh tidak langsung melalui pemberdayaan sebesar 0,0489 (4,89\%), sehingga diketahui total pengaruh tidak langsung iklim organisasi terhadap kinerja komite sekolah sebesar 0,1187 $(11,87 \%)$, dan total pengaruh iklim organisasi terhadap kinerja komite sekolah sebesar 0,2297 (22,97\%). Adanya pengaruh iklim organisasi terhadap kinerja komite sekolah secara parsial, dibuktikan dengan uji hipotesis yang signifikan serta relevan dengan hasil analisis deskriptif di mana iklim organisasi sudah berjalan dengan kondusif. Hasil penelitian ini memperkuat teori yang dikemukakan Davis dan Newstrom (2005), bahwa iklim organisasi merupakan lingkungan dimana para pegawai dalam suatu organisasi melakukan pekerjaannya. Iklim organisasi mengitari dan mempengaruhi segala hal yang bekerja dalam organisasi sehingga iklim dikatakan sebagai suatu konsep yang dinamis berdampak pada kinerja organisasi. Demikian pula pemberdayaan, secara parsial memiliki pengaruh langsung terhadap kinerja komite sekolah sebesar 0,0562 (5,62\%), pengaruh tidak langsung melalui kepemimpinan sebesar 0,0378 (3,78\%), pengaruh tidak langsung melalui iklim organisasi sebesar $0,0489(4,89 \%)$, sehingga diketahui total pengaruh tidak langsung pemberdayaan terhadap kinerja komite sekolah sebesar $0,0867 \quad(8,67 \%)$, dan total pengaruh pemberdayaan terhadap kinerja komite sekolah sebesar 0,1430 (14,30\%.). Adanya pengaruh pemberdayaan terhadap kinerja organisasi dibuktikan dengan uji hipotesis yang signifikan, juga relevan dengan hasil analisis deskriptif di mana pemberdayaan dalam kondisi cukup baik dalam arti telah berjalan sesuai kebutuhan, walaupun masih terdapat kelemahan. Hasil penelitian sejalan dengan apa yang dikemukakan Wibowo (2008), bahwa pemberdayaan merupakan peru- bahan yang terjadi pada filsafat manajemen yang dapat membantu menciptakan suatu lingkungan di mana setiap individu dapat menggunakan kemampuan dan energinya untuk meraih tujuan organisasi. Seorang karyawan memiliki wewenang dan berinisiatif untuk melakukan sesuatu yang dipandang perlu, jauh melebihi tugasnya sehari-harimana setiap individu dapat menggunakan kemampuan dan energinya untuk meraih tujuan organisasi. Seorang karyawan memiliki wewenang dan berinisiatif untuk melakukan sesuatu yang dipandang perlu, jauh melebihi tugasnya sehari-hari.

Selain itu, berdasarkan hasil analisis jalur yang tertera pada gambar 1 dan hasil uji hipotesis dengan uji-F, dapat disimpul- kan bahwa kepemimpinan, iklim organisasi dan pemberdayaan memberikan pengaruh secara simultan terhadap kinerja komite sekolah sebesar 65,60\%, sisanya sebesar $34,40 \%$ merupakan variabel yang mempe- ngaruhi 
kinerja komite sekolah tetapi tidak diteliti. Faktor-faktor tersebut antara lain implementasi kebijakan, budaya organisasi, ketersediaan sarana prasarana. pemahaman masyarakat, dan proses recruitment SDM, yaitu masalah-masalah yang ditemukan saat observasi awal.

\section{PENUTUP}

Berdasarkan penelitian tentang kepemimpinan, iklim organisasi, dan pemberdayaan terhadap kinerja komite sekolah SLTA se-Wilayah Priangan Timur, disimpulkan sebagai berikut.

Hasil analisis deskriptif, berdasarkan persepsi responden bahwa kepemimpinan berada pada kondisi cukup baik, namun terdapat kelemahan dalam peningkatan keaktifan anggota dalam melaksanakan suatu keputusan dan menentukan tempat pelaksanaan pekerjaan; Iklim organisasi cukup kondusif, namun masih terdapat kelemahan dalam hal pemberian imbalan kepada pengurus dan pemberian penghargaan setelah selesai melakukan pekerjaan; Pemberdayaan telah berjalan dengan cukup baik, namun masih terdapat kelemahan dalam hal membuat pengurus menjadi mampu dan dalam bekerjasama; Kinerja komite sekolah berada dalam kondisi cukup baik, namun terdapat kelemahan dalam hal memberikan pertimbangan terhadap kriteria kinerja tenaga kependidikan dan menganalisis ide, tuntutan, dan kebutuhan pendidikan yang diajukan masyarakat.

Hasil analisis verifikatif membuktikan bahwa kepemimpinan, iklim organisasi, dan pemberdayaan secara parsial memiliki hubungan asosiatif dengan kinerja komite sekolah dan berpengaruh baik langsung maupun tidak langsung. Kepemimp;inan, iklim organisasi, dan pemberdayaan secara simultan berpengaruh signifikan terhadap kinerja komite sekolah.

\section{DAFTAR PUSTAKA}

Carlitz, Ruth. (2016), Promoting Active Engagement of School Management Committees in Tanzania: A Research Proposal, Cega. berkeley.edu, page:1- 23.
Hardono, Haryono, dan Yusuf, Amin. (2017), Kepemimpinan Kepala Sekolah Supervisi Akademik, dan Motivasi Kerja dalam Meningkatkan Kinerja Guru, 6(1), 26-33.

Hartajunika, Gerry; Sujana, Edy; dan Atmadja, Anantawikrama Tungga.(2013), FaktorFaktor yang Mempengaruhi Kinerja Organisasi Sektor Publik (Studi Empiris Pada Kantor Dinas Tenaga Kerja dan Transmigrasi Kabupaten Buleleng), 3(1), 1-12.

Hamdan, (2018), Industri 4.0: Pengaruh Revolusi Industri Pada Kewirausahaan Demi Kemandirian Ekonomi, 3(2), 1-8.

Marsofiyati dan Febriantina, Susan, (2016), Pemberdayaan Komite Sekolah dalam Meningkatkan Efisiensi Pengelolaan Sekolah di Kota Depok (Studi Kasus pada Komite SMAIT Al-Qudwah KotaDepok), 14(2), 201-224.

Megiati, Yunita Endra, (2016),

Pemberdayaan Komite Sekolah: Kajian Konsep dan Implementasinya, 1(2), 125134.

Nawawi, Hadari dan Martini Hadari. (2004). Ilmu Administrasi. Jakarta: Galia Indonesia.

Nyandoro, Joyce; Mapfumo, John; Makoni, Ricahrd, (2013). Effectiveness Of School Development Committees In Financial Management In Chimanimani West Circuit Primary Schools In Zimbabwe, 4(1), 255-274.

Permendiknas RI No.044/U/2002, tentang Dewan Pendidikan dan Komite Sekolah.

Rahman, Moh. Ainur dan Prasetya, Arik, (2018), Pengaruh Kepemimpinan dan Komunikasi Organisasi Terhadap Kinerja Karyawan; Studi PadaKaryawan PT Jatim Times Network di Kota Malang, 63(1), 82-89.

Radianto, Ari dan Sunuharjo, BambangSwasto (2017), Pengaruh Iklim Organisasi dan Budaya Organisasi Terhadap Kinerja Karyawan, 53(1), 14-20.

Rêgo, Elvino Bonaparte do, Supartha, Wayan Gede, dan Yasa, Ni Nyoman Kerti (2017), Pengaruh Kepemimpinan Terhadap 
Motivasi dan Kinerja Karyawan pada Dirjen Administrasi dan Keuangan, Kementerian Estatal Timor leste (11), 3731-3764.

Satya, Venti Eka, (2018), Strategi Indonesia Menghadapi Industri 4.0 , 10(9),19-24. Setiawan, Kiki Cahaya, (2015), Pengaruh Iklim Organisasi Terhadap Kinerja Karyawan Level Pelaksana Di Divisi Operasi Pt. Pusri Palembang, 1(1), 2332.

Sulasmono, Bambang Suteng dan Murjini, (2017), Evaluasi Kinerja Komite Sekolah dalam Peningkatan Mutu Pendidikan, 6(1), 113-121.

Yehezkiel, Masjaya, dan Rosa Anggraeny, (2014), Pengaruh Kepemimpinan dan Iklim Organisasi Terhadap Kinerja Pegawai Pada UPTD Pengembangan Produktivitas Daerah Disnakertrans Provinsi Kalimantan Timur, 2(1), 1-13.

\section{BIOGRAFI PENULIS}

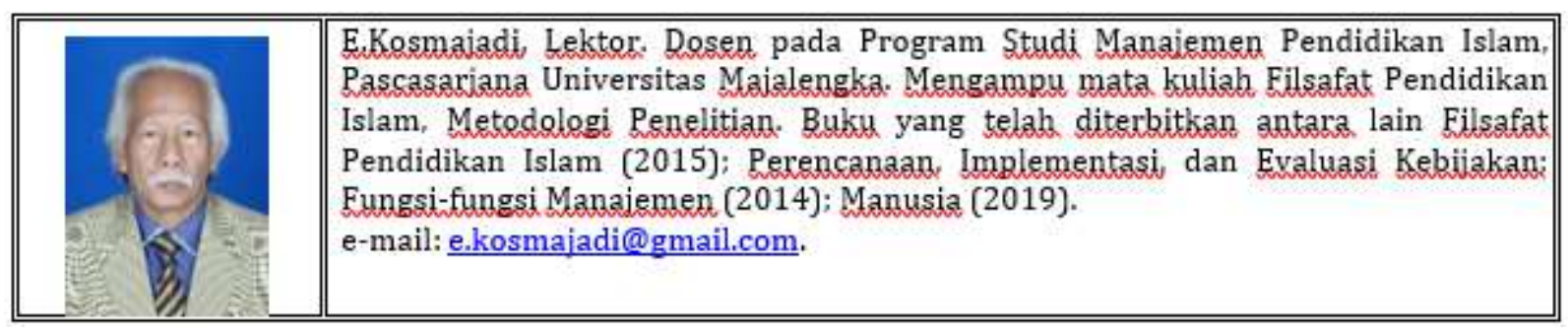

